\title{
VARIABILITY OF MORPHOMETRIC PARAMETERS IN NATURALIZED AND CULTIVATED Hydrangea macrophylla Ser. PLANTS UNDER DIFFERENT ENVIRONMENTAL CONDITIONS
}

\section{V.I. MALYAROVSKAYA}

All-Russian Research Institute of Floriculture and Subtropical Crops, Russian Academy of Agricultural Sciences, 2/28, ul. Yana Fabriciusa, Sochi, 354002 Russia, e-mail subplod@mail.ru, malyarovskaya@yandex.ru Received December 10, 2013

\section{Abstract}

Plants cultivated in humid subtropics of Russia are mostly exotic species. One of them, Hydrangea macrophylla Ser., can grow in city parks and gardens, as well as in the forest of Sochi suburb as a component of adventive flora, thus, the $H$. macrophylla habitat conditions differ significantly. To estimate the genetic resources, implement breeding programs and optimize plant cultivation, an adaptability and intraspecial variability of plants must be evaluated. In our observation in Sochi region during 2006-2008 carried out on the Black Sea coast (in the gardenmuseum «Tree of Friendship» and in Kuban Subtropical Botanic Garden) and in the mountain area (Krasnaya Polyana and Solokh-Aul settlements), a phenotypic variability of morphological traits was analyzed in naturalized and cultivated $H$. macrophylla plants (Madame Faustin Travouillon and Madame Faustin Travouillon cultivars), and an influence of the external conditions to the range of variations was investigated. It was shown that genotype considerably influenced the plant height $(63.5 \%)$, leaf length $(82.0 \%)$, inflorescence diameter $(19.3 \%)$ and bract length $(84.1 \%)$. Climatic factors of the year also affected leaf width in both cultivars $(22.5 \%)$. With increase in height above sea level $(400-600 \mathrm{~m}$ in settlements Krasnaya Polyana and Solokh-Aul) most of the morphometric parameters increased. Maximum changes were observed in inflorescence diameter and bract length (30.1-55.4 \% in Madame Faustin Travouillon and 26.5-71.5\% in Madame Maurice Hamard), indicating optimization of a complex of abiotic and edaphic factors at this high-rise level. The lowest variability (5.5-12.3\%) was indicated in shoot length both in cultivated and naturalized plants. In general, naturalized and cultivated plants differed considerably. The bract length and inflorescence diameter were the most variable, at 37.5$80.1 \%$ and $17.9-31.2 \%$, respectively, when compared in $H$. macrophylla from city biocoenoses and settlements of Krasnaya Polyana and Solokh-Aul being higher in naturalized plants. Leaf length variation in cultivated plants ranged from 15.8 to $20.7 \%$ being at $34.9 \%$ in plants grown in Solokh-Aul. Thus, the range of variability on most of the tested morphological traits was wider in the naturalized plants if compared to the cultivated plants with slightly changed parameters. Therefore, the plants growing in city biocoenosis are more leveled on an individual development.

Keywords: morphometric parameters, Hydrangea macrophylla, plant introduction, wild, cultigenic and city coenosis.

The humid subtropics of Russia are referred to the region where natural vegetation has been almost displaced by urban phytocenoses. Most of the plants growing in this territory belong to alien species. A considerable number of them take their origin from the East-Asian floristic region where the climatic conditions are similar to those in the considered area.

At present, in connection with at first spontaneous and then systematic introduction of plants in botanical gardens, as well as with the wide use of exotic species in landscape gardening and amateur horticulture, the facts when alien plants run wild become increasingly frequent [1]. Formation of introduced plant populations is observed all over the world [2], and the humid subtropics of Russia are not an exception in this respect.

One of the alien species, which belong to the family Hydrangeaceae and are used for landscape gardening, is the large-leaved hydrangea, Hydrangea macrophylla Ser. The intraspecies diversity of this bush is represented by a large 
number (about 800) of cultivars and garden forms [3]. Under the conditions of the region, $H$. macrophylla plants are found both in urban cenoses (parks, public gardens, etc.) and as the component of the adventive flora in the suburban forests of Big Sochi. Feral plants of the species $H$. macrophylla usually grow on clear-boled forest plots and on river banks [4].

It is known that morphological characters of species may vary depending on environmental conditions [5-15]. Studying the degree of morphological parameter variation allows us to reveal the most stable characters, which is important in breeding work. However, the scientifically grounded description of characters is impossible without the assessment of their variability [16].

The purpose of this work was to investigate the phenotypic variability of morphological characters of naturalized and cultigenic Hydrangea macrophylla plants, as well as the influence of habitat conditions on the variation range of these characters.

Technique. The studies were carried out in 2006-2008 (the size of each sample was about 250 plants) on cultivars Madame Faustin Travouillon and Madame Maurice Hamard which are most common in the region and grow under cultivation on the Black Sea coast in the Friendship Tree Garden Museum (Sochi) and Kuban Subtropical Botanical Garden (Sochi), as well as in mountainous areas in the settlements of Krasnaya Polyana and Solokh-Aul (Sochi). Measurements and calculations were carried out with regard to five morphological characters: sprout length $(1, \mathrm{~cm})$, leaf length $\left(\mathrm{l}_{1}, \mathrm{~cm}\right)$, leaf width $(\mathrm{b}, \mathrm{cm})$, inflorescence diameter $(\mathrm{d}, \mathrm{cm})$, bract length $\left(\mathrm{l}_{2}, \mathrm{~cm}\right)$. Mature leaves were taken from the middle part of sprouts on the southern side. The inflorescence diameter and bract length (sample size of 2,500 pcs) were also measured on the southern side.

The $H$. macrophylla morphological variability in different environmental conditions was assessed based on the value of the variation coefficient in accordance with the following scale: $<7 \%$ as very low, $8-15 \%$ as low, $16-25 \%$ as medium, $26-35 \%$ as increased, $36-50 \%$ as high, $>50 \%$ as very high $[16,17]$.

The obtained data were processed using statistics methods [18].

Results. The comparative analysis of naturalized and cultigenic $\mathrm{H}$. macrophylla plants has shown that the environmental conditions of the habitat have a significant positive influence on the linear characters associated with the generative sphere. The greatest variability was observed for the bract length and the diameter of the inflorescences collected from plants under the conditions of urban cenoses and from naturalized plants near the settlements of Krasnaya Polyana and Solokh-Aul.

High variation coefficient values $(37.5-80.1 \%)$ were noted for the bract length character (Table 1). The amplitude of inflorescence diameter variability for H. macrophylla plants ranged from $17.9 \%$ (medium) to $31.2 \%$ (increased).

1. Morphological parameters of Hydrangea macrophylla plants depending on growth conditions $\left(X \pm S_{X}\right.$, Sochi, 2006-2008)

\begin{tabular}{|c|c|c|c|c|}
\hline Parameter & $\begin{array}{l}\text { Friendship Tree } \\
\text { Garden Museum }\end{array}$ & $\begin{array}{l}\text { Kuban Subtropical Botani- } \\
\text { cal Garden }\end{array}$ & Krasnaya Polyana & Solokh-Aul \\
\hline \multicolumn{5}{|c|}{ Madame Faustin Travouillon } \\
\hline $1, \mathrm{~cm}$ & $126.5 \pm 2.1$ & $134.7 \pm 1.4$ & $189.8 \pm 2.1$ & $224.5 \pm 2.4$ \\
\hline$C V, \%$ & 5.4 & 4.9 & 10.1 & 14.4 \\
\hline $1_{1}, \mathrm{~cm}$ & $17.5 \pm 0.9$ & $18.6 \pm 1.0$ & $18.3 \pm 0.8$ & $19.1 \pm 0.9$ \\
\hline$C V, \%$ & 15.8 & 20.7 & 23.8 & 24.5 \\
\hline $\mathrm{b}, \mathrm{cm}$ & $12.3 \pm 0.4$ & $12.7 \pm 0.9$ & $13.0 \pm 0.7$ & $13.3 \pm 1.1$ \\
\hline$C V, \%$ & 20.3 & 25.2 & 27.8 & 34.9 \\
\hline $\mathrm{d}, \mathrm{cm}$ & $18.0 \pm 1.4$ & $18.5 \pm 1.1$ & $17.3 \pm 1.5$ & $17.5 \pm 1.1$ \\
\hline$C V, \%$ & 17.9 & 21.1 & 28.7 & 31.2 \\
\hline
\end{tabular}




\begin{tabular}{|c|c|c|c|c|}
\hline & & & & Table 1 (continued) \\
\hline $1_{2}, \mathrm{~cm}$ & $0.9 \pm 0.2$ & $0.9 \pm 0.2$ & $0.8 \pm 0.1$ & $0.9 \pm 0.1$ \\
\hline$C V, \%$ & 37.5 & 41.0 & 48.7 & 62.0 \\
\hline \multicolumn{5}{|c|}{ Madame Maurice $\mathrm{Hamard}$} \\
\hline $1, \mathrm{~cm}$ & $120.3 \pm 2.4$ & $123.6 \pm 1.9$ & $175.5 \pm 1.9$ & $213.8 \pm 1.8$ \\
\hline$C V, \%$ & 6.3 & 5.4 & 6.9 & 11.5 \\
\hline $1_{1}, \mathrm{~cm}$ & $13.6 \pm 0.3$ & $13.9 \pm 0.4$ & $13.1 \pm 0.7$ & $14.0 \pm 0.6$ \\
\hline$C V, \%$ & 19.3 & 17.5 & 31.8 & 32.2 \\
\hline $\mathrm{b}, \mathrm{cm}$ & $12.3 \pm 0.8$ & $12.5 \pm 0.9$ & $11.8 \pm 0.8$ & $12.0 \pm 1.0$ \\
\hline$C V, \%$ & 23.1 & 22.3 & 25.0 & 28.7 \\
\hline $\mathrm{d}, \mathrm{cm}$ & $18.3 \pm 1.0$ & $18.6 \pm 1.2$ & $19.0 \pm 0.2$ & $18.5 \pm 0.4$ \\
\hline$C V, \%$ & 17.9 & 23.9 & 25.9 & 27.1 \\
\hline $1_{2}, \mathrm{~cm}$ & $2.1 \pm 0.2$ & $2.2 \pm 0.2$ & $3.0 \pm 0.8$ & $3.9 \pm 0.9$ \\
\hline $\mathrm{CV}, \%$ & 53.8 & 37.6 & 62.8 & 80.1 \\
\hline $\begin{array}{l}\text { Note: } \\
\text { with en }\end{array}$ & $\begin{array}{l}\text { th, } 1_{1-l e a f} \\
\text { tion coeffic }\end{array}$ & h, b-leaf width, d-inflor & scence diameter, $1_{2} \_$br & ngth, $X \pm S_{X-\text { average }}$ \\
\hline
\end{tabular}

The characters associated with linear dimensions of leaves also varied. Thus, medium variability was noted for the leaf length of the plants growing under the conditions of urban cenoses (from 15.8 to $20.7 \%$ ). In H. macrophylla populations in the lower mountain belt, the amplitude of the variation of this character was somewhat higher and ranged from 23.8 to $32.2 \%$. The variability with regard to the leaf width in plant populations from the settlement of Solokh-Aul was $34.9 \%$.

The instability of morphometric characters of $H$. macrophylla leaves may be due to variations of soil humidity, air temperature and humidity in the period of spring and summer plant sprout growth. Also, these parameters may depend on the age of sprouts, the ratio between generative and vegetative organs on sprouts, or the age-specific condition of the plants growing in different environmental conditions.

The high variation amplitude for 3 years of observations is explained by substantial climatic differences of these years. Particularly, 2006 was the most favorable year for the majority of the investigated characters in the populations under study (Table 2).

2. Morphological parameters of naturalized Hydrangea macrophylla plants in different years (Solokh-Aul, Krasnaya Polyana and Sochi)

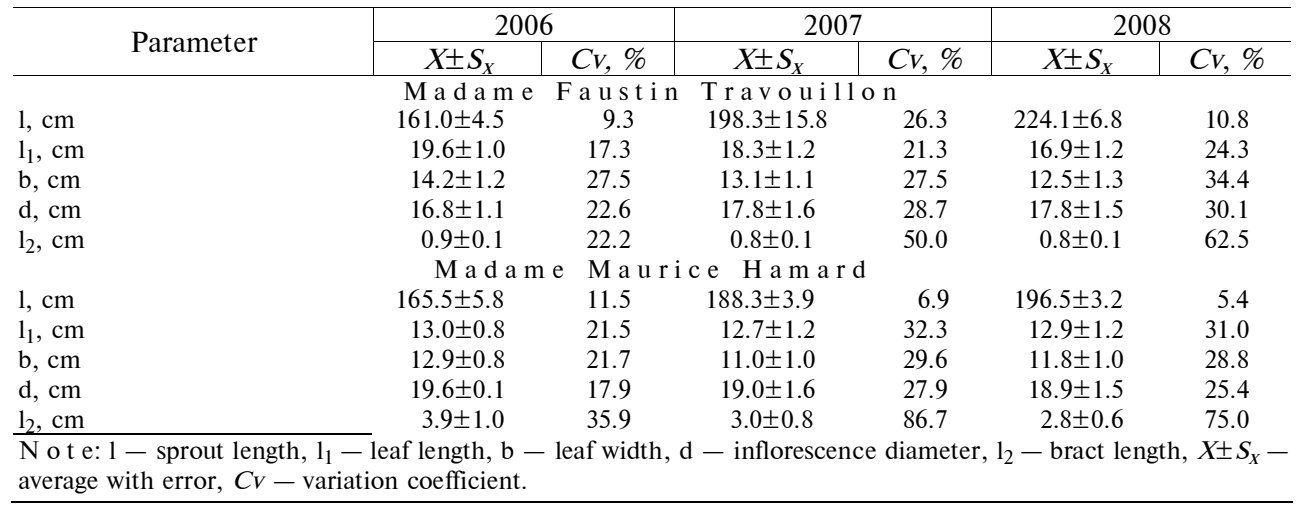

In that year, the amount of precipitation was by $25.2 \%$ larger than the long-time annual average value, which had a positive impact on the stability of the studied characters of plants in populations.

The sprout length variability was low (5.4-11.5\%). The year of 2007 was an exception because well-marked differences between plants in the population were noted for cv. Madame Faustin Travouillon with regard to this character (26.3\%).

Naturalized $H$. macrophylla plants demonstrated the variation of linear 
dimensions of leaves by years from $17.3 \%$ (medium) for cv. Madame Faustin Travouillon in 2006 to $32.3 \%$ (high) for cv. Madame Maurice Hamard in 2007.

Variability was found with regard to the leaf width, in 2008 from increased (28.8 \%) for cv. Madame Maurice Hamard to high (34.4 \%) for cv. Madame Faustin Travouillon. The inflorescence diameter ranged from 22.6 (2006) to $30.1 \%$ (2008) for cv. Madame Faustin Travouillon and from 17.9 (2006) to $27.9 \%$ (2007) for cv. Madame Maurice Hamard. Very high variability was noted with regard to the bract length in 2007-2008, being 50.0-62.5\% for cv. Madame Faustin Travouillon and 86.7-75.0 \% for cv. Madame Maurice Hamard.

Within the period of the studies, no strong development of $H$. macrophylla plants was observed under the conditions of urban cenoses in the absence of competition. The morphological variability for the cultivated plants was less than that in populations of naturalized plants (Table 3 ).

The sprout length variability for the studied cultivars was shown to be low (3.8-6.6\%), the variation of linear dimensions of leaves being from medium $(16.8 \%)$ to increased $(25.2 \%)$. Similar results were obtained with regard to the inflorescence diameter. High variability was only noted for the bract length (33.3-58.3\%).

3. The parameters of morphological characters of Hydrangea macrophylla plants in urban cenoses in different years (Sochi)

\begin{tabular}{|c|c|c|c|c|c|c|}
\hline \multirow{2}{*}{ Parameter } & \multicolumn{2}{|c|}{2006} & \multicolumn{2}{|c|}{2007} & \multicolumn{2}{|c|}{2008} \\
\hline & $X \pm S_{X}$ & $C V, \%$ & $X \pm S_{X}$ & $C v, \%$ & $X \pm S_{X}$ & $C v, \%$ \\
\hline \multicolumn{7}{|c|}{ Madame Faustin Travouillon } \\
\hline $1, \mathrm{~cm}$ & $133.5 \pm 2.0$ & 5.2 & $130.9 \pm 1.8$ & 4.5 & $129.9 \pm 1.5$ & 3.8 \\
\hline $1_{1}, \mathrm{~cm}$ & $19.0 \pm 0.9$ & 16.8 & $18.5 \pm 1.1$ & 20.0 & $17.6 \pm 1.2$ & 23.3 \\
\hline $\mathrm{b}, \mathrm{cm}$ & $13.1 \pm 0.9$ & 22.1 & $12.3 \pm 0.8$ & 20.3 & $12.7 \pm 1.0$ & 25.2 \\
\hline $\mathrm{d}, \mathrm{cm}$ & $19.0 \pm 0.8$ & 14.7 & $17.5 \pm 1.1$ & 21.1 & $17.5 \pm 0.9$ & 17.1 \\
\hline $1_{2}, \mathrm{~cm}$ & $0.9 \pm 0.1$ & 22.2 & $0.9 \pm 0.1$ & 37.5 & $0.8 \pm 0.1$ & 41.1 \\
\hline \multicolumn{7}{|c|}{ Madame Maurice $\mathrm{Hamard}$} \\
\hline $1, \mathrm{~cm}$ & $125.0 \pm 2.5$ & 6.6 & $126.1 \pm 2.1$ & 5.4 & $120.7 \pm 1.8$ & 4.8 \\
\hline $1_{1}, \mathrm{~cm}$ & $14.4 \pm 0.8$ & 19.4 & $13.1 \pm 0.8$ & 19.8 & $13.5 \pm 0.7$ & 16.3 \\
\hline $\mathrm{b}, \mathrm{cm}$ & $12.5 \pm 0.9$ & 24.0 & $12.8 \pm 0.8$ & 21.9 & $12.4 \pm 0.9$ & 23.4 \\
\hline $\mathrm{d}, \mathrm{cm}$ & $18.7 \pm 1.0$ & 17.1 & $17.5 \pm 1.2$ & 21.7 & $18.6 \pm 1.0$ & 17.2 \\
\hline $1_{2}, \mathrm{~cm}$ & $2.3 \pm 0.2$ & 34.5 & $2.1 \pm 0.2$ & 33.3 & $2.4 \pm 0.4$ & 58.3 \\
\hline
\end{tabular}

4. The parameters of morphological characters in the populations of naturalized and cultivated Hydrangea macrophylla plants (Solokh-Aul, Sochi, 2006-2008)

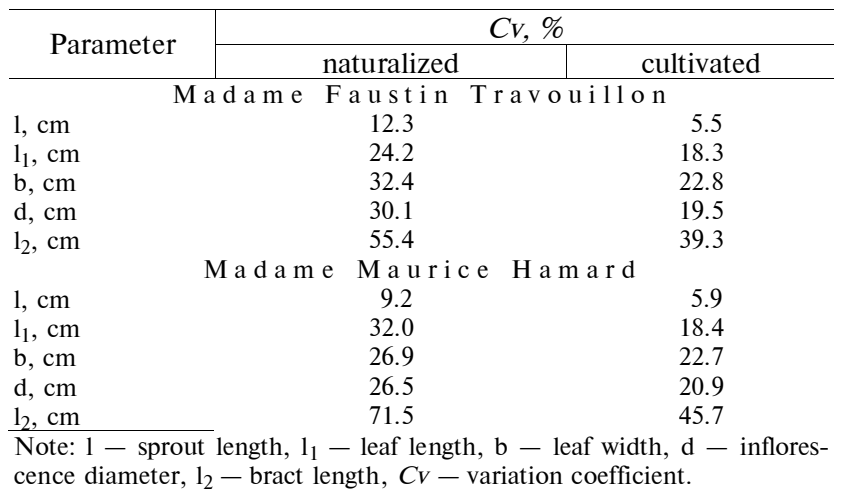
The leaf length was characterized by medium variability (18.3-18.4\%), and the same can be said of the inflorescence diameter. Increased variability was observed with regard to the leaf width $(22.8 \%)$. In case of cultivated plants, 
the high variability was only noted for the generative character, the bract length (39.3-45.7 \%).

At the same time, morphological characters in the populations of naturalized $H$. macrophylla plants demonstrated the increased or very high variability, for example, 55.4-71.5\% in case of the bract length.

The influence of the genotype and year conditions on morphological characters of garden forms was assessed using the two-factor analysis-of-variance method (Table 5). The influence of the $H$. macrophylla genotype on all studied characters turned out to be statistically significant. The contribution of «genotype» factor variance was from $19.3 \%$ (inflorescence diameter) to $84.1 \%$ (bract length). The contribution of «year conditions» factor variance ranged from 1.8 $\%$ (bract length) to $22.5 \%$ (leaf width). Only $3.2 \%$ was accounted for the variance of «leaf length»-«year conditions» factor interaction, whereas the contribution of the variance of «leaf width»-«year conditions» factor interaction was equal to $47.3 \%$.

5. The structure of morphological variability for Hydrangea macrophylla garden plants, based on the results of the analysis of variance (Sochi, 2006-2008)

\begin{tabular}{|c|c|c|c|c|c|}
\hline Factor & df & $\mathrm{mS}$ & $F$ & Variance & $\begin{array}{l}\text { Factor } \\
\text { contribution, } \%\end{array}$ \\
\hline \multicolumn{6}{|c|}{ Plant height, cm } \\
\hline Genotype & 3 & 37.991 & $97.6^{*}$ & 1121 & 63.5 \\
\hline Year conditions & 2 & 3.645 & $9.5^{*}$ & 99 & 5.6 \\
\hline Interaction & 6 & 1.814 & $4.7^{*}$ & 162 & 9.2 \\
\hline Unaccounted & 120 & 383 & - & 383 & 21.7 \\
\hline \multicolumn{6}{|c|}{ Le a f le $\mathrm{ngth}, \mathrm{cm}$} \\
\hline Genotype & 3 & 285.0 & $244.1^{*}$ & 8.7 & 82.0 \\
\hline Year conditions & 2 & 19.1 & $16.4^{*}$ & 0.4 & 3.8 \\
\hline Interaction & 6 & 4.1 & $3.6^{*}$ & 0.3 & 3.2 \\
\hline Unaccounted & 120 & 1.2 & - & 1.2 & 11.0 \\
\hline \multicolumn{6}{|c|}{ Le a f width, cm } \\
\hline Genotype & 3 & 4.5 & $3.9^{*}$ & 0.102 & 2.4 \\
\hline Year conditions & 2 & 42.7 & $36.6^{*}$ & 0.943 & 22.5 \\
\hline Interaction & 6 & 18.6 & $16.0 *$ & 1.987 & 47.3 \\
\hline Unaccounted & 120 & 1.2 & - & 1.200 & 27.8 \\
\hline \multicolumn{6}{|c|}{ Inflorescence diameter, cm } \\
\hline Genotype & 3 & 17.9 & $11.0^{*}$ & 0.490 & 19.3 \\
\hline Year conditions & 2 & 4.4 & $2.7^{*}$ & 0.060 & 2.3 \\
\hline Interaction & 6 & 4.7 & $2.9^{*}$ & 0.350 & 13.8 \\
\hline \multirow[t]{2}{*}{ Unaccounted } & 120 & 1.6 & - & 1.630 & 64.6 \\
\hline & \multicolumn{5}{|c|}{ Bract length, cm } \\
\hline Genotype & 3 & 45.79 & $323.5^{*}$ & 1.320 & 84.1 \\
\hline Year conditions & 2 & 1.46 & $10.3^{*}$ & 0.030 & 1.8 \\
\hline Interaction & 6 & 0.90 & $6.4^{*}$ & 0.090 & 5.5 \\
\hline Unaccounted & 120 & 0.14 & - & 0.140 & 2.6 \\
\hline \multicolumn{6}{|c|}{$\begin{array}{l}\text { Not e: df }- \text { number of degrees of freedom for factor, } \mathrm{mS}-\text { mean square, } F-\text { Fisher's variance ratio. Dash } \\
\text { means no data. } \\
{ }^{*} \mathrm{P}<0.05 \text {. }\end{array}$} \\
\hline
\end{tabular}

Therefore, the genotype had the most significant influence on the variation of such morphological characters as plant height, leaf length and bract length. The largest influence on the variation of the leaf width of the studied cultivars was noted in case of the year conditions, which was significantly confirmed by the high percentage characterizing the interaction of these factors.

The values of most of the morphometric characters increased with the increase of altitude above sea level (the settlements of Krasnaya Polyana and Solokh-Aul). At the altitude of 400-600 m, generative characters (inflorescence diameter and bract length) had the largest variation coefficient for cv. Madame Faustin Travouillon (30.1-55.4 \%) and cv. Madame Maurice Hamard (26.5$71.5 \%$ ), which indicates the optimization of conditions with regard to a set of abiotic and edaphic factors. The lowest variability (5.5-12.3\%) was noted for the 
sprout length in the populations of both cultivated and naturalized plants.

The obtained results are consistent with data from other researchers who have demonstrated that the variability of the characters attributable to the number of any particular plant organs or components is not similar to the level of variability in the linear parameters [19-21].

Thus, adventive Hydrangea macrophylla plants in the natural environment substantially differ from cultigenic plants in absolute morphometric parameters. The variation range for most of the studied characters is larger for the first group of plants than for the latter one. The morphometric characters for the cultivated plants vary insignificantly, i.e. the $H$. macrophylla plants growing under the conditions of urban cenoses were more uniform with regard to the individual development.

\section{REFERENCES}

1. Karpu n Yu.N. V sbornike: Ekologicheskie problemy introduktsii rastenii na sovremennom etape: voprosy teorii i praktiki [In: Modern ecological problems of plant introduction: theoretical and practical aspects. Part 2]. Krasnodar, 1982, chast' 2: 15-17.

2. P e trov A.P., La d e is h c hi k ov a G.V. Materialy konferentsii «170 let so dnya rozhdeniya osnovatelya Sochinskogo Dendrariya S.N. Khudekova» [Proc. Conf. «170 years since the birth of S.N. Khudekov, the founder of Cochi Arboretum».]. Sochi, 2007: 35-37.

3. G e ld e r e $n$ C.J., G e ld e r e $n$ D.M. Encyclopedia of Hydrangeas. Portland-Cambridge, 2004.

4. P i n'k ovski i M.D., S o $1 \mathrm{t}$ a n i G.A. V sbornike nauchnykh trudov: Dekorativnoe sadovodstvo Rossii [In: Landscape gardening in Russia. Issue 42, V. 1]. Sochi, 2009, vypusk 42, tom 1: 46-54.

5. Ste p a nova N.T. Zavisimost' morfologicheskikh priznakov trutovykh gribov ot zonal'nosti i vertikal'noi poyasnosti. Ekologiya, 1972, 3: 13-19.

6. Kulikov G.V., Ruguzov I.A. Izmenchivost' anatomicheskikh pokazatelei lista tisa yagodnogo v zavisimosti ot uslovii mestoobitaniya. Ekologiya, 1973, 1: 90-93.

7. Gorchakovski i P.L., Zueva V.N. Vnutripopulyatsionnaya i mezhpopulyatsionnaya izmenchivost' ural'skikh endemichnykh astragalov. Ekologiya, 1982, 4: 20-27.

8. $\quad \mathrm{K}$ h u z i n a G.R. Vestnik Udmurdskogo universiteta, 2011, 3: 47-52.

9. K hi k m at u 11 i n a G.R. Vestnik Udmurdskogo universiteta, 2013, 2: 48-57.

10. B a rche nk ov A.P. Izmenchivost' vidov roda Larix Mill. $v$ Srednei Sibiri. Avtoreferat kandidatskoi dissertatsii [Variability of Larix Mill. species in Middle Siberia. PhD Thesis]. Krasnoyarsk, 2007.

11. Shu X., Yang X., Yang Zh. Variation in seed and seedling traits among fifteen Shinese provenances of Magnolia officinalis. Not. Bot. Horti. Agrobo., 2012, 40(2): 274-283.

12. Baranova O.G., Dedyukhina O.N., Kramar' O.A., Markova E.M., Y a g o v k i n a O.V. Populyatsionnaya biologiya, 2009, 1: 3-10.

13. B a rna M. Adaptation of European beech (Fagus sylvatica L.) to different ecological conditions: leaf size variation. Polish J. Ecol., 2004, 52: 34-45.

14. Ï ó i k o њ K., W i o d z i m i e r z M. A simple technique of random leaf collecting for biometric studies in a tree stand. Biodiv. Res. Conserv., 2009, 15: 29-34.

15. Freeman D.C., Brown M.L., Duda J.J., Graraham J.H., Emlen J.M., Krzysik A.J., B albach Y., Kovacic D.A., Z a k J.C. Leaf fluctuating asymmetry, soil disturbance and plant stress: a multiple year comparasion using two herbs, Ipomoea pandurata and Cnidoscolus stimulosus. Ecol. Indicat., 2005, 5: 85-95. (doi: 10.1016/j.ecolind.2004.05.002).

16. M a ma e v S.A. V sbornike: Zakonomernosti formoobrazovaniya $i$ differentsiatsii vida $u$ drevesnykh rastenii [In: Regularities of species formation and differentiation in woody plants]. Sverdlovsk, 1969: 3-38.

17. M a g o m e d m i z a e v M.M. Obshchaya biologiya, 1976, 37(3): 331-343.

18. L a k i n G.F. Biometriya [Biometry]. Moscow, 1990.

19. Z a i t s e v a Z.D. Ekologiya, 1972, 5: 74-79.

20. Zaits e v T.A. Ekologiya, 1985, 4: 73-75.

21. Abdulla eva E.A., As a d u la ev Z.M. Materialy Mezhdunarodnoi nauchno-prakticheskoi konferentsii «Dekorativnoe sadovodstvo Rossii» [Proc. Int. Conf. «Landscape gardening in Russia»]. Sochi, 2009: 54-59. 